\title{
STRUGGLE IN H. G. WELLS' NOVEL THE ISLAND OF DOCTOR MOREAU
}

\author{
Yudi Kurniawan, Muhammad Fatih Suhadi \\ Faculty of Literature, Universitas Islam Sumatera Utara \\ Medan, Indonesia \\ e-mail: yudi.sastra.inggris@gmail.com
}

Received: 2021-10-16

Accepted: 2021-11-21

\begin{abstract}
This study constitutes an identification of the protagonist's struggle in H. G. Wells' novel The Island of Doctor Moreau. This study discusses the story of an English shipwreck survivor named Edward Prendick who is rescued from an accident and taken to an unnamed island to be mended by Montgomery. He is a man of science who works for Doctor Moreau in the island. The story deals with Prendick's struggle to maintain his sanity due to Doctor Moreau terrifyingly peculiar works of vivisection practices. This study focuses on Doctor Moreau through Prendick's point of view. Prendick, as the protagonist, experiences both internal and external struggle. He has to choose between saving his life or to obey Dr. Moreau to do his evil bidding. Otherwise, he has to keep his composure to blend with the island people. This study adopts descriptive qualitative method to characterise the mental struggle experienced by the protagonist. The study concludes that the protagonist experiences significant amount of both internal and external struggle throughout the story. The recommendation of this story is a moral lesson. The lesson is to face struggle head-on so you can defeat it. Hopefully, this study can be of relevance in future studies regarding the topic discussed in this study.
\end{abstract}

Keywords: struggle, protagonist, sanity

\section{Introduction}

Humans are bound to face adversities in life whether we like it or not. Some might say that adversity will present to us at some point in life. It is like saying that water is wet, an undeniable truth. But, on every stormy cloud, there will always be silver lining where the beautiful sun is taking a peek at us ready to shine its warm sunlight towards earth. There is not much differences between that and adversity. It is right to say that facing adversity or struggling is not as sweet as one might presume how winning a huge lottery feels like. But it is important to see life through positive perspective. Every setback has its reason and purpose. Every failure is followed by learning curve. To struggle is to evolve. To evolve is to improve. In the end, that is what we need to do in life if we want to be the best version of ourselves.

Struggle is one of a few ideas displayed throughout the novel used for this study. In this novel, struggles are one of main aspects that affect the protagonist, and in extent, to everyone. Therefore, this study is to help identify the struggles that often come at someone. The protagonist's struggle is chosen because this novel is a narrative from the 
protagonist's point of view. As a result, the protagonist's struggle has the broadest sample which can help maximise the analysis in this study.

This paper limits the scope of the study to stay relevant with the chosen topic. In this study, the writer focuses the identification only on the protagonist's struggles. The struggles experienced by the protagonist in the novel revolves around his experience living in an island with a grotesque vivid section specialist called Doctor Moreau. Topics other than struggles are not discussed in this study.

\section{Literature Review}

\subsection{Protagonist}

A protagonist is the main character whose story is being told, often playing the role of hero or heroine. The word "protagonist" comes from the Greek word protagonists, meaning "first combatant," and refers to the leading character, aided by the chorus in classical Greek tragedy.

Hull (2013) says that protagonist is who the story is about. He also stated that protagonist pursues the goal of the story who, sometimes, is played by the main character. In other words, protagonist and main character are often the same. Fowler (1987: 32) adds that the protagonist is the main character in a story, novel, drama, or any literary work, the character that the reader or audience empathizes with.

According to the definitions above, it can be said that a protagonist represents the positive things in the story. The role of the character is likely to be a figure that is usually favoured and of noble identity and causes or at least the character that keeps the audience invested in the story because the quality of a literary work can be encapsulated by the quality of the protagonist themselves.

\subsection{Struggle}

Colins (1968: 26) defines that struggle is not easy, sometimes it also needs sacrifice in order to get purpose. Although, happy ending will not always come as the result of the struggle. Everyone wants to be the best version of themselves by standing upright in the face of adversaries. Difficulties come with certain struggles as struggle is one part of difficulties we tend to face in life.

Burleson (1964: 30) says that struggle is one of ways to reach the better life in the future and to increase the prestige. It means that any hope will be achieved through struggling. In relation with Burleson, Krishnanada (1989: 34) adds struggle might be fulfilled in various ways. It is due to different barriers and limitation faced by everyone in their lives. In addition, someone who has different dream may have different struggle. However, one who really wants to achieve their goals in life, they will struggle hard to face any obstacles coming towards them.

Life is a series of achievements, and every path we take in our lives leads towards different results or outcomes. To struggle is to progress with difficulty, to make a strenuous effort or to be engaged with a problem. Struggle is done in overcoming our difficulties. Every strand of our lives has its own sets of difficulties, whether it is work related, relationship, or interpersonal. Facing difficulties means that we as human being struggle. If we walk past it victoriously, we are nothing but evolved as a human being. Even if it's only mentally evolving, every achievement needs to be cherished. It means we matured, grew, and improved. 


\subsubsection{Internal Struggle}

An internal struggle is the struggle occurring within a character's mind. Things such as the character views for but can't quite reach. As opposed to external conflict, in which a character is grappling some force of themself, such as wars or a chain-breaking off a bike, or not being able to get past a roadblock. The dilemma posed by internal struggle is usually some ethical or emotional question. Indicators of internal struggle would be a character's hesitation or self-posing questions like "what was it I did wrong?"

Internal conflict is a conflict within a figure. This conflict was called mental conflict because a character against itself to determine and resolve something that exposes itself. (Nurgiyantoro, 2010:124).

\subsubsection{External Struggle}

External conflict is a struggle that takes place between the main character and some outside force. Therefore, it is outside the body of the protagonist. Usually, it occurs when the protagonist struggles against the antagonist, a character that opposes the protagonist in the main body of the story. Other types of external conflict could also arise due to some other factors such as the forces of nature, and society in which the protagonist lives.

\subsection{Differences between Internal and External Struggle}

In a nutshell, internal struggle is the struggle that comes from within such as feeling scared or any negative feelings whatsoever. On the other hand, external struggle is the struggle that comes from outside your being like feeling thirsty because there is no water nearby, or something as simple as getting splinter on the tip of your finger. Of course, both kinds of struggle affects each other, but the main difference is the source.

\section{Research Method}

This study is conducted by using qualitative method. Koul (1984: 1990) adds that qualitative research method is conducted by studying the organised material in order to discover inherent facts. The content analysis, inductive analysis, and logical analysis are mostly used in the analysis of qualitative material. Yin (1989: 29) also adds that in principle, any research design can use any type of data collection method and can use either quantitative or qualitative data. Furthermore, the study is presented in descriptive form.

In a study, data collection is to make main purpose of the study easier to achieve. Data collection shows how the writer collects the data to be analyzed systematically. This study uses library research. According to Herbert (1990: 18) library research is a research to collect ideas, theories, and reported empirical data within the context of scholarship in the library. Therefore, this method is adopted in this study to gather the data.

\section{Results and Discussion 4.1 Internal Struggle}

The data and analysis of the study based on the approach used to analyse the novel are presented to reveal the answer of the problem identification. The following quotations show how the problem of this study are described. 
The protagonist is experiencing internal struggle so desperate that he thinks of drinking sea-water to hydrate himself that leads to his death. But, sadly he is unable to do it because he has not enough power even to walk towards the sea. This is the instance of internal struggle that affects external struggle greatly. The quotation below describes the situation.

I lay across one of the thwarts for I know not how long, think ing that if I had the strength I would drink sea-water and madden myself to die quickly. (Wells, 1896: 11)

Then, the following part is taken from the novel. It shows that the protagonist finds struggle to speak. The struggle to speak is very hard for the protagonist in the novel. He cannot express anything by showing it through his facial expression. This shows the deep state of internal struggle as if trying to recollect his own memory is something difficult for him.

I think I said I felt all right. I could not recollect how I had got there. He must have seen the question in my face, for my voice was inaccessible to me. (Wells, 1896: 13)

The protagonist also gets mental attack from his health condition. Because of his sickness, his mental is so brittle. It makes him separate. Therefore, he tries hard to survive. This is shown in the following quotation.

"You were nearly dead," said my interlocutor. "It was a very near thing, indeed. But I've put some stuff into you now. Notice your arm's sore? Injections. You've been insensible for nearly thirty hours." (Wells, 1896: 14)

The quotation above tells us that the deterioration of the protagonist's health condition makes him have a conversation with himself inside his mind. This is the example of internal struggle that affects one's own brain, rendering him hallucinating.

At last I must confess my voice suddenly broke in the middle of a vigorous threat. I felt a gust of hysterical petulance, and went aft and stared dismally at nothing. (Wells, 1896: 31)

The paragraph above describes that the threat chasing after the protagonist really surprises him to the point that even before that he was unable to utter anything vocally, suddenly he is able to do so. This is an example of an internal struggle that is overridden by his external struggle.

I was alternately despairful and desperate. Once or twice as I stood waiting there for things to accomplish themselves. I could not resist an impulse to laugh at my miserable quandary. I felt all the wretcheder for the lack of a breakfast. Hunger and a lack of blood-corpuscles take all the manhood from a man. (Wells, 1896: 32)

Based on the quotation above, it is shown that the struggle of the protagonist is very harsh. He is very low in energy. He is so desperate of the situation that he cannot think of anything or other than waiting for time to solve the problem by itself. 
Presently that work was finished, and then came a struggle. I was hauled, resisting weakly enough, to the gangway. (Wells, 1896: 32)

From the quotation above, the terrible conditions of the protagonist seem to never end. From one bad circumstance follows another one. This is an example of seemingly prolonged internal struggle that affects him externally.

Abruptly the cruelty of this desertion became clear to me. I had no means of reaching the land unless I should chance to drift there. I was still weak, you must remember, from my exposure in the boat; I was empty and very faint, or I should have had more heart. But as it was I suddenly began to sob and weep, as I had never done since I was a little child. The tears ran down my face. In a passion of despair I struck with my fists at the water in the bottom of the boat, and kicked savagely at the gunwale. I prayed aloud for God to let me die. (Wells, 1896: 33)

The quotation above describes about how desperate the situation is for the protagonist He thinks of letting himself die. This shows that his struggle is so great that he thinks being dead is not so bad.

I had, as it were passed the limit of terror and despair. I felt now that my life was practically lost, and that persuasion made me capable of daring anything. (Wells, 1896: 71)

When he is hiding behind a bush and then he senses that there is another thing chasing him. The thing makes him unable to rest because of the fear. This is an example of internal struggle that is magnified by his external struggle.

I had to act with the utmost circumspection to save myself from the suspicion of insanity. My memory of the Law, of the two dead sailors, of the ambuscades of the darkness, of the body in the canebrake, haunted me; and, unnatural as it seems, with my return to mankind came, instead of that confidence and sympathy I had expected, a strange enhancement of the uncertainty and dread I had experienced during my stay upon the island. No one would believe me; I was almost as queer to men as I had been to the Beast People. I may have caught something of the natural wildness of my companions. They say that terror is a disease, and anyhow I can witness that for several years now a restless fear has dwelt in my mind, --such a restless fear as a half-tamed lion cub may feel. (Wells, 1896: 173)

The quotation above describes that the protagonist is very aware of what happened on him, and he doubts when he returns to his home people will believe in his stories.

\subsection{External Struggle}

The quotation below tells that the protagonist is able to survive from that moment because the threat coming after him is not as bad as the other character who suffers a lot worse. This shows the variety of external struggles experienced by the 
I say luckily for us he did not reach us, and I might most say luckily for himself; for we had only a small beaker of water and some soddened ship's biscuits with us, so sudden had been the alarm, so unprepared the ship for any disaster.

(Wells, 1896: 10)

The protagonist and the other members of the drifter suffered of terrible hunger because the only things that they have in that moment are a small number of biscuits and a small portion of drinkable water, which can only save them for a short moment. After that they must struggle with hunger. An external struggle of limited resources.

We drifted famishing, and, after our water had come to an end, tormented by an intolerable thirst, for eight days altogether.

(Wells, 1896: 10)

After the first day we said little to one another, and lay in our places in the boat and stared at the horizon, or watched, with eyes that grew larger and more haggard every day, the misery and weakness gaining upon our companions. The sun became pitiless. The water ended on the fourth day, and were already thinking strange things and saying them with our eyes; but it was, I think, the sixth before Helmar gave voice to the thing we had all been thinking. I remember our voices were dry and thin, so that we bent towards one another and spared our words. (Wells, 1896: 10-11)

The quotation above tells that the group of hungry and thirsty men lost almost their sanity and energy. They are even barely able to utter their voice. The example of external struggle due to limited supplement to survive the day.

I remember how my head swayed with the seas, and the horizon with the sail above it danced up and down; but I also remember as distinctly that I had a persuasion that I was dead, and that I thought what a jest it was that they should come too late by such a little to catch me in my body. (Wells, 1896: 12)

The quotation above describes about how desperate the situation is for the protagonist that he thinks he is already dead and then his body will get caught by the beasts. The example of external struggle that renders the protagonist incapable of differentiating between living and dying.

At the same time my eye caught my hand, so thin that it looked like a dirty skin-purse full of loose bones, and all the business of the boat came back to me. (Wells, 1896: 13)

From the quotation above, it shows the struggle of finding food is eminent. Because of the lack of food and water, the protagonist couldn't consume anything for many days that his body is burnt out, resulting in a very skinny body. He notices that extreme change when he looks at his own hand.

I was too faint, what with my long fast and the sun beating down on

my bare head, to offer any assistance. (Wells, 1896: 34) 
The protagonist, in the quotation above, is too exhausted that he cannot provide anything to help with the work. The external struggle of limited food and drinks is making him difficult to think about some solution of how to escape the situation.

It was some time before I could summon resolution to go down through the trees and bushes upon the flank of the headland to the beach. At last I did it at a run; and as I emerged from the thicket upon the sand, I heard some other body come crashing after me. At that I completely lost my head with fear, and began running along the sand. (Wells, 1896: 61)

So long as I live, I shall remember the terror of that chase. I ran near the water's edge, and heard every now and then the splash of the feet that gained upon me.

(Wells, 1896: 61-62)

The quotations above describe the struggle of the protagonist when he is hiding behind a bush and then he senses that there is another thing chasing him which makes him unable to rest because of the fear.

My last remaining strength slipped from me, and my head fell forward on my chest. I think he found a certain satisfaction in giving me brandy.

(Wells, 1896: 63)

He asked me no questions, but gave me some more brandy and water and pressed me to eat. I was in a state of collapse.

(Wells, 1896: 64)

From the quotations above, the protagonist was in the verge of his consciousness, when suddenly someone gives him brandy and water and food. This is an example of external struggle that can be solved externally.

Even as that fear came back to me came a cry from within; but this time it was not the cry of a puma. (Wells, 1896: 66)

The quotation above describes the struggle of the protagonist when he is hearing another cry from a creature but it's not the same sound as before. The external struggle that makes him dreadful of not knowing what's out there lurking at him.

I stretched my limbs, sore and painful from the pricks of the spiny plants, and stared around me at the trees; and, so suddenly that it seemed to jump out of the green tracery about it, my eyes lit upon a black face watching me. (Wells, 1896: 71)

From the quotation above, it tells that the protagonist struggles from facing one creature to another, after he manages to run from one, another one shows up. This is an example of overcoming one struggle only to find the next one.

"Let go," said I; and the body of Montgomery vanished with a splash.

Something seemed to tighten across my chest. "Good!" said I, with a

break in my voice; and they came back, hurrying and fearful, to the 
margin of the water, having long wakes of black in the silver. (Wells, 1896: 151-152)

The quotation above describes the struggle of the protagonist when he is hiding behind a bush and then he senses that there is another thing chasing him which makes him unable to rest because of the fear. This is an example of external struggle that affects his mind.

I was anxious to be alone, to think out the position in which I was now placed. A dreadful thing that I was only beginning to realise was, that over all this island there was now no safe place where I could be alone and secure to rest or sleep. (Wells, 1896: 153)

The quote above tells the struggle of the protagonist when he realises that there is safe place in that island because of the abundance of the beasts, he cannot even rest even for a while. This is an example of constant external struggle, knowing he cannot be safe even for awhile.

Then I came round to the Hyena-swine. I felt sure that if I did not kill that brute, he would kill me. (Wells, 1896: 154)

The quotation above describes when another threat shows up in front of the protagonist, and this time it's a ferocious Hyena-swine creature. He is sure that running away will not secure his life, so he is thinking of a way to kill it.

Towards noon certain of them came and squatted basking in the hot sand. The imperious voices of hunger and thirst prevailed over my dread. I came out of the bushes, and, revolver in hand, walked down towards these seated figures. One, a Wolf-woman, turned her head and stared at me, and then the others. None attempted to rise or salute me. I felt too faint and weary to insist, and I let the moment pass.

(Wells, 1896: 155-156)

Edward's struggle, based on the quote above, comes to the time when he meets another type of beast in the shape of Wolf-woman. But this time he is too exhausted to even budge, so he just keeps himself as where he is and decides not to do anything.

I heard something breathing, saw something crouched together close beside me. I held my breath, trying to see what it was. It began to move slowly, interminably. Then something soft and warm and moist passed across my hand. All my muscles contracted. I snatched my hand away. A cry of alarm began and was stifled in my throat. Then I just realized what had happened sufficiently to stay my fingers on the revolver. (Wells, 1896: 157)

Another threat is looming upon the protagonist. The quotation above tells that there is another beast coming from behind and touches his hand. Edward is terrified and alarmed.

After analysing the data, there are some findings that can be presented. First, it is found that there are internal and external struggles carried out by the protagonist in H.G. Wells' the Island of Doctor Moreau. The struggles are illustrated when the protagonist has to overcome his fear of Doctor Moreau, he could escape him; when the 
protagonist has to face the beast people in the village, he knows they dislike him being among them and being in constant amount of dread the entire time the protagonist is with them. Second, it is found that the protagonist carries out the struggle by running, fighting, and facing different people and beings. It means that the protagonist is virtually in constant state of struggle, both internally and externally. Finally, it is quite often to find internal struggle that affects the protagonist externally. For instance, he is being so scared to spend the night that he got sleep deprived. Then, the external struggle affects him internally. As an example, he is being so hungry that he cannot operate his brain to think right.

\section{Conclusion}

The study concludes that the topic of this study is present in almost every chapter of the novel. It is also concluded that the protagonist experiences internal and external struggle in almost every step of the way the story proceeds. Some struggle is more severe than the other; whereas, other examples of struggle affect the other kind. The internal struggle affects the protagonist externally, and vice versa. The final conclusion of this study is that both internal and external struggle is an aspect of a character in the story that cannot be ignored. It cannot be omitted out of the story.

\section{References}

Burleson, B. (1964). Human behavior. New York: Haricot Bruce and World Inc.

Colins, C. Carter. (1968). A student's guide to literature. New York: Washington Square Press, Inc.

Fowler, A. L. (1987). A history of literature. London: Basil Blackwell Ltd.

Herbert, Martin. (1990). Planning a research project. London: Cassel.

Hull, J. (2013). The true definition of a protagonist. Retrieved from http://www.narrativefirst.com/articles/the-true-definition-of-a-protagonist.

Koul, L. (1984). Methodology of education research. New Delhi: Vikas Publishing House.

Krishnananda, S. S. (1989). The struggle for perfection. India: The Divine Life House

Nurgiyantoro, Burhan. (2010). Teori pengkajian fiksi. Yogyakarta: Gajah Mada. University Press.

Wells, H., G. (1896). The island of doctor moreau. New York: Stone and Kimball MDCCCXCVI.

Yin. (1989). Application of case study research. Sage: Sage Publication Ltd. 